Journal of Education and Vocational Research

Vol. 3, No. 11, pp. 370-386, Nov 2012 (ISSN 2221-2590)

\title{
Academic Internationalization: The Impact of Mobility and Technology
}

\author{
${ }^{1}$ Charlotte B. Broaden*, 2Daria C. Crawley \\ ${ }^{1}$ Southern New Hampshire University, School of Business, Manchester \\ ${ }^{2}$ Robert Morris University, School of Business, University Boulevard Moon Township \\ *c.broaden@snhu.edu
}

\begin{abstract}
The education industry has been transformed, in part, due to the impact of globalization. Globalization has created shifting paradigms in the way educational services are designed, how they are delivered and where they are located. For academic institutions to deal with these shifts; they will need to develop strategies, policies, and procedures that address issues related to globalization, the movement of resources (human, financial and physical) and the application of technology. Faculty, and how they perceive their role in shaping an internationalized academy, will be crucial in this process. In this paper, we examine academic roles, opportunities, and challenges, in an era of global change, while proposing a model of institutional internationalization that addresses the impact of mobility and technology on the academy.
\end{abstract}

Keywords: Academic, internationalization, mobility, technology

\section{Introduction}

The education industry has been transformed, in part, due to the impact of globalization. Globalization has created shifting paradigms in the way educational services are designed, how they are delivered and where they are located. These shifts are driven by the increased demand by emerging economies to raise the level of performance and competencies of their populations; the identification of efficient delivery of educational services through technological advances; acknowledgment of decreasing enrollments of "traditional students (18-24 yr olds)"; the re-entry of adult learners seeking to upgrade job skills; changing immigration regulations; and competitive pressures to follow education industry leaders who have globalized their operations. While traditional student enrollments are declining, this population poses an even bigger challenge in the delivery of educational services. Today's students are technology savvy. These "digital natives" are dependent upon technology, and this will impact how they learn and how they may need to be taught. On the other hand, adult learners may need assistance to increase their technical skills to compete with their younger counterparts. Faculty will need to assess their own technology capabilities and adjust to this changing landscape of technology in the classroom. In addition to the challenge related to technology, the adult learner population is highly mobile and they need the flexibility of an educational delivery system that fits with their lifestyle. Educational institutions seeking to capture a growing share of this market have to develop plans to mobilize its resources, (human, financial, and physical), to adjust to these shifting paradigms. For academic institutions to deal with these shifts; they will need to develop strategies, policies, and procedures that address these issues of globalization, technology, and mobility. Faculty, and how they perceive their role in shaping an internationalized academy, will be crucial in this process. In this paper, we examine academic roles, opportunities, and challenges, in an era of global change, while proposing a model of institutional internationalization that addresses the impact of mobility and technology on the academy. This study provides a gateway for institutions to examine a framework for internationalizing their operations. Growing competition in the education industry will dictate that institutions investigate all avenues for opportunities to create competitive advantage in the market. They must do this while delivering high quality educational services, via multiple delivery mediums, to a varied audience. For faculty members, internationalizing the institution provides career options to explore teaching opportunities beyond the home border, in addition to infusing the curriculum with advanced technology and alternate delivery systems. Students benefit from an internationalized institution that gives them flexibility of choice in their educational endeavors. 


\section{The Nature of Academic Work}

Careers in the field of academia have traditionally been based on an "onward and upward" mentality (Collin and Young, 2000). Driver (1994) noted that academics have long been considered an international community of scholars whose careers are in many ways "steady and linear". This linear progression through the ranks is based on the scholar's ability to amass an impressive portfolio of activities in three traditional areas: teaching, research, and service. Within some institutions there is the added requirement of completing these tasks within a specific timeframe in order to achieve tenure. Much of the work of academics is done independently or isolation, beginning with the dissertation and the desire to establish oneself in a field of talented peers. While there may be occasion to seek collaboration, there are rewards for separating and establishing yourself as an expert in your chosen field. Altbach and Lewis (1996) noted that the professorate everywhere is faced with many challenges and are well aware of the problems they face in an era of worldwide fiscal constraints for higher education and increased demands for productivity. Among the challenges noted were issues with the resources given them to carry out their work, such as: classrooms, laboratories, research equipment, libraries and with the technologies available for teaching. Additionally, it was noted that "classes are getting larger, academics are under pressure to teach more, funds available for research are declining, and salaries are not keeping abreast of inflation" (1996). In general, there was ample evidence that the professorial working conditions are deteriorating in many parts of the world. This traditional model of a career in higher education, based on hierarchy and progression in a single organization seems to be shifting (Eaton and Bailyn, 2000; Handy, 1994; Kanter, 1989). Research suggests that increasing opportunities for faculty to teach in distance education programs connected to institutions outside of their home country, the globalization of the North American MBA and expansion of education throughout Asia, The Middle East, and South America represent "pull" factors which may impact academics international mobility (Richardson and Zikic, 2007). On the other hand "push" factors such as the abolition of the tenure system in British universities, the inability of universities in developing countries to retain "homegrown" faculty who are attracted to fill the shortage of faculty and perceived higher salaries in other countries may also play a role (Richardson and Zikic, 2007; Schuster, 1994). The American Council on Education (ACE, 2005) released a report indicating that critical work-life dilemmas indicate an urgent need for higher education leaders to examine and proactively address the institutional climate that governs the entire career cycle of faculty. The report highlights the following reasons for examining the internal institutional climate: a tightening academic job market is forcing new PhDs to leave academia or opt for careers outside of the traditional tenure-track path, barriers to promotion in rank especially for women, dual career families; research opportunities and a host of other factors are making the case for a new model. As we examine a proposed model for institutional internationalization that can impact the career of the professorate, it is also important to understand options to a traditional career path for academics. To do this, understanding a framework for institutional internationalization is an important starting point.

\section{Theoretical perspectives on institutional internationalization}

Rask, Strandskov, and Haksonsson (2008) discuss four theoretical perspectives on why firms internationalize. These include: an institutional-economic perspective that presupposes that conditions within the organization constitute the necessary, but insufficient condition, which determines whether the business activities may be internationalized; a learning perspective that indicates decisions about how future actions are formed on the basis of retrospective interpretation; a strategic perspective, which focuses on the element of competition and notes that internationalization choices take place on various levels based on the analysis of competitors; and finally, an inter-organizational perspective, which views an organization's interaction with other players from an angle of power and influence. The first two perspectives are driven by internal factors within the institution, while the latter two are driven by external factors. For institutions of higher learning, Hughes (2008) notes there are three main drivers of internationalization: student mobility, staff mobility, and offshore delivery.

Student mobility- An important component in institutional internationalization is the mobility of students. Statistics indicate significant increases in the number of students enrolled outside their country of citizenship, from 0.8 million worldwide in 1975 to 3.7 million in 2009, a more than fourfold increase (OECD, 2011) and the levels have been projected to rise to 7.2 million by 2025 (Bohm, Davis, Meares and Pearce, 2002). 
Statistics for the 4300 US colleges and universities (1700 public, 1600 private non-profit, 1000 for profit private) indicate that they generate over $\$ 400$ billion in revenue, $60 \%$ from state operated public schools and $40 \%$ by private schools (Hoovers, 2010). The market for cross border students accounts for billions of dollars, hence there is major competition among institutions of higher education to attract foreign students, to generate income and for some, increase profit. It appears that the majority of the flow is from developing to developed OECD countries. The US attracts the single largest share of foreign students followed by the UK, France, Australia, Germany, and Japan. One factor that is important about student mobility is where students are coming from and where they are headed. Table 1 provides a snapshot from the 2008 United Nations Educational, Scientific, and Cultural Organization (UNESCO) data base.

Table 1: International or Internationally Mobile Students - 2009 and 2010

\begin{tabular}{|c|c|c|c|c|c|c|c|}
\hline & Africa & $\begin{array}{l}\text { North America, } \\
\text { Central America \& the } \\
\text { Caribbean }\end{array}$ & $\begin{array}{l}\text { South } \\
\text { America }\end{array}$ & $\begin{array}{l}\text { Asia \& the } \\
\text { Middle } \\
\text { East }\end{array}$ & $\begin{array}{l}\text { European } \\
\text { Union }\end{array}$ & Oceania & Total \\
\hline Students & 36,734 & 60,827 & 32,545 & 479,393 & 70,150 & 5,049 & 684,714 \\
\hline Coming To: & 35,164 & 24,470 & 3,557 & 178,513 & 117,592 & 2,208 & 368,968 \\
\hline US & 106,957 & 8,871 & 9,921 & 55,123 & 52,532 & 381 & 249,143 \\
\hline UK & 7,695 & 7,996 & 2,657 & 203,913 & 10,757 & 4,544 & 257,637 \\
\hline France* & 17,333 & 6,126 & 5,828 & 65,597 & 86,617 & 445 & 197,895 \\
\hline Australia* & 1,071 & 2,730 & 1,137 & 122,691 & 3,437 & 518 & 131,599 \\
\hline \multicolumn{8}{|l|}{ Germany* } \\
\hline Japan & & & & & & & \\
\hline
\end{tabular}

This dynamic, however, may be changing in the future. Due to the efforts developed by European nations resulting from the Bologna Accords; the process to create the European Higher Education Area (EHEA), one single and coherent space for higher education will result in the most comprehensive reform of European education systems in the past thirty years (Wachter, 2009). On at least a political level, the Bologna Process has been deemed a success and this program is considered a role model in many parts of the world (Zgaga, 2006). The main question is whether students see this process as a success. As noted, the table below provides a synopsis from Fulbright's program for graduate students conducting research around the world.

Table 2: Fulbright - Graduate Students

\begin{tabular}{lllllll}
\hline Year & Africa & $\begin{array}{l}\text { East } \\
\text { Asia }\end{array}$ & $\begin{array}{l}\text { Europe/ } \\
\text { Eurasia }\end{array}$ & $\begin{array}{l}\text { Near } \\
\text { North Africa }\end{array}$ & $\begin{array}{l}\text { East } \\
\text { Asia }\end{array}$ & $\begin{array}{l}\text { Western } \\
\text { Hemisphere }\end{array}$ \\
\hline 2008 & 70 & 210 & 395 & 99 & 53 & 178 \\
2009 & 67 & 184 & 393 & 97 & $* *$ & 186 \\
2010 & 67 & 190 & 403 & $100^{*}$ & $* *$ & $* *$ \\
2011 & & & & & &
\end{tabular}

Source: http://www.fulbrightonline.org./documents; ${ }^{*}$ anticipated ${ }^{* *}$ figures not available

While numbers alone are not a true measure of success, it can be noted that for the past three years, as it relates to Fulbright graduate students, there has been significant attraction to the Europe/Eurasia area. These numbers have practically doubled what has taken place in the Western Hemisphere for the same time period. This may be a signal that efforts developed via the EHEA are beginning to reap benefits for the Europe/Eurasia region.

Faculty (scholar) mobility - The emphasis on faculty or scholar mobility can be viewed from a variety of perspectives. In some countries and regions, scholars face enormous hardships and setbacks, while in other regions scholars enjoy a high degree of independence and academic freedom, with state-of-the-art equipment and up to date information. These differences contribute to scholarly mobility and at the same time result in uneven patterns of scholarly mobility (O'Hara, 2009). In 2011 institutional financial support funding faculty internationalization activities declined which raises questions around the investment of resources to strengthen faculty capacity (ACE, 2012). The work of scholars has a broad impact on the academy and society as a whole, yet the true measure of this impact has been difficult to measure. With approximately 655,000 
full-time faculties, at over 4300 academic institutions that vary significantly in size and degree level, the US has the largest higher education capacity in the world (Hoovers, 2010). However, in comparison to the rest of the world, the number of outbound US scholars is relatively low with only a third reporting that they had taken at least one trip abroad (Altbach and Lewis, 1996). For example, during the 2009-2010 academic year a total of 2755 U.S. citizens received Fulbright grants to study abroad and in contrast 4244 Fulbright grants were awarded to foreign nationals (U.S. Department of State, 2011). The pattern of mobility outside of the U.S. is shown in Table 3.

Table 3: U.S. Scholarly Mobility by Region - 2009-2010

\begin{tabular}{lllll}
\hline U.S. Fulbright Scholars* & $\mathbf{2 0 0 8 - 2 0 0 9}$ & $\mathbf{2 0 0 9 - 2 0 1 0}$ & \\
\hline Africa & 96 & 76 & \\
East Asia and the Pacific & 217 & 191 & \\
Europe & 657 & 513 & \\
Near East & 85 & 78 & \\
South and Central Asia & 82 & 110 & & \\
Western Hemisphere & 250 & 193 & & \\
\hline Source: Fulbright Foreign & Scholarship Board Annual Report 2008-2009 & and & 2009-2010 \\
http://fulbright.state.gov & & & & \\
*Research Scholars, Lecturing Scholars, Teacher Exchange, or Seminars & &
\end{tabular}

By contrast, mobility to the US has been increasing. The Institute of International Education (2011) reported that in the 2010-2011 academic year an estimated 115,000 foreign scholars from 193 places of origin taught and conducted research at over 400 colleges and universities in the US. This is an eight percent increase over the previous year and marks a steady increase over the past twenty years. Review of the Fulbright Scholar program data indicates that in 2009850 international scholars came to the U.S. for a year or semester to teach and/or conduct research. In comparison in 2010, 987 international scholars came to the U.S. (IIE, 2011). The pattern of mobility into the US for this time period is shown in table 4.

Table 4: International Scholarly Mobility by Region - 2009-2010

\begin{tabular}{ll}
\hline International Fulbright Scholars* & $\mathbf{2 0 0 9 - 2 0 1 0}$ \\
\hline Africa & 84 \\
East Asia and the Pacific & 269 \\
Europe & 430 \\
Near East & 104 \\
South and Central Asia & 133 \\
Western Hemisphere & 128 \\
\hline
\end{tabular}

Source: Fulbright Foreign Scholarship Board Annual Report 2009-2010 http://fulbright.state.gov

*Research Scholars, Lecturing Scholars, Teacher Exchange, or Seminars

Data in regards to scholarly mobility to the US shows that the majority of scholars coming to the US are from the Asia/Pacific region closely followed by Europe. A similar pattern of mobility can be seen with the Fulbright scholar program.

Offshore delivery - Offshore delivery can take on different forms, such as online education, study abroad programs or university managed overseas operations. The presence of the Internet has facilitated an uncommon rise of online instruction (Simonson, Smaldino, Albright and Zvacek, 2006). Research conducted by the Sloan Consortium shows that $83 \%$ of colleges and universities now offer courses at a distance (Allen and Seaman, 2007). Moreover, the percent of undergraduate students enrolled in at least one distance education class doubled between $1999-2000$ and $2003-2004$ from $8 \%$ to $16 \%$ and increased to $20 \%$ during the 2007-2008 academic years (Radford, 2010). Chen (2009) reported on statistics taken from a National Center for Education Statistics survey, for the academic year 2000-2001 the most recent public dataset. The data shows a breakdown by institution type in regards to the adoption of technology mediated distance learning offered by US educational institutions. 
Table 5: Adoption of Technology Mediated Distance Education by Institution Type (2000-2001)

\begin{tabular}{llllll}
\hline $\begin{array}{l}\text { Distance Education } \\
\text { Offering }\end{array}$ & $\begin{array}{l}\text { Public } \\
\text { 2-Year }\end{array}$ & $\begin{array}{l}\text { Private } \\
\text { 2-Year }\end{array}$ & $\begin{array}{l}\text { Public } \\
\text { 4-Year }\end{array}$ & $\begin{array}{l}\text { Private } \\
\text { 4-Year }\end{array}$ & Total \\
\hline Adopted & 481 & 17 & 363 & 250 & 1,111 \\
Not Adopted & 24 & 81 & 32 & 252 & 389 \\
Total & 505 & 98 & 395 & 502 & 1,500 \\
\hline
\end{tabular}

Source: Chen (2009), Barriers to adoption of technology-mediated distance education in higher education institutions.

Public institutions overall, showed a greater adoption to technology mediated distance education, than did their private counterparts. For smaller universities with less national cachet, it might mean an opportunity to grow the brand and enroll students from across the country, even the globe. Institutions need to determine how online or technology based services fit or adapt to their mission. A 2008 study "Staying the Course, Online Education in the United States", supported by the Sloan Consortium indicates that institutions believe that online education will open up their enrollments to more students outside of their normal service area (Allen and Seaman, 2008). There is a drawback, however, in that students like online learning, but they also like the tangibility of having a real campus nearby. The proliferation of distance education may also blur the lines and how institutions define an "international student" in the future (Chow and Bhandari, 2011). New generation conferencing software, such as Skype, may be able to bring the physical environment of a classroom just a bit more closely into the online experience. The information in table 6, adapted from the 2010 Sloan report, provides an indication of how critical online education and technology is to the long term strategy of various institutions.

Table 6: Proportion of Chief Academic Officers in Agreement with the Criticality of Online Education (Technology Based Services) to Long-term Strategy - fall 2009

\begin{tabular}{llllll}
\hline & $\begin{array}{l}\text { Carnegie } \\
\text { Classifications } \\
\text { Public }\end{array}$ & $\begin{array}{l}\text { Private } \\
\text { Non-profit }\end{array}$ & $\begin{array}{l}\text { Private } \\
\text { For-profit }\end{array}$ & \\
\hline Percent Agreeing & $73.6 \%$ & $49.5 \%$ & $50.7 \%$ & & \\
& & Master's & Baccalaureate & Associate's & Specialized \\
Percent Agreeing & $69.7 \%$ & $64.5 \%$ & $32.7 \%$ & $65.7 \%$ & $61.2 \%$ \\
& Under 1500 & $1500-2999$ & $3000-7499$ & $7500-14999$ & $15000+$ \\
Percent Agreeing & 48.0 & $63.5 \%$ & $70.5 \%$ & $71.5 \%$ & $80.8 \%$ \\
\hline
\end{tabular}

Source: Allen, E. and J. Seaman (2010), Learning on Demand, Online Education in the United States, 2009

The observed pattern of agreement, using the Carnegie Classification, institutional control and institutional size indicates that online education is most important to the long term strategy of public institutions and least important to the private non-profits. Baccalaureate institutions have the lowest rating of believing online (technology based) education is strategic. Except for the smallest of institutions, the majority of institutions of all sizes believe that online education is critical to their long term strategy. For those institutions that are able to integrate technology based services into the internationalization process, their global reach will become more advantageous. As noted earlier in our work, institutions must take into account the development cost of such systems, marketing issues as well as faculty participation, in order to successfully implement a technology based program. Chen (2009) noted in his study that program development costs had a greater impact on the decision to adopt technology mediated distance education than any other factor. Another factor to consider in the adoption of technology based distance education is faculty participation. For those institutions currently engaged in distance education, lack of faculty participation can be a barrier to more wide spread adoption of online education (Allen and Seaman, 2007). Other researchers have noted that barriers to teaching and learning at a distance often impede faculty from adapting to new educational opportunities. Such barriers include technical expertise, faculty compensation and time, and attitudes towards technology (Berge, 2002; Chen, Voorhees and Rein, 2006; Green, Alejandro \& Brown, 2009). To better understand the impact of offshore delivery of educational programs, it is important to understand the nature of the education industry. The education industry is categorized as a service industry, and as such falls under the General Agreement on Trade in Services (GATS). GATS' defines four ways in which a service can be 
traded: cross border supply; consumption abroad; commercial presence; and presence of natural persons. GATS will have a major impact on the types of tertiary institutions created abroad and on the presence of private universities in many parts of the world. GATS' operates under a system of commitments, some general and some voluntary.

Education is considered a voluntary commitment, for this reason, the World Trade Organization (WTO) member nations will need to decide upon the degree of access to provide for different education sectors, but once agreed upon, all members are to be treated equally (OECD, 2004). Trade in higher education services is a billion dollar industry that includes the recruitment of international students, establishment of university campuses abroad, franchised provision and online learning (Knight, 2002). Educational institutions and educational professionals are realigning themselves to meet the challenges and demands of operating in this fast-growing global sector. There are however, some challenges to offshore delivery of international education. Education like other professional service can be plagued by several factors, including marketing related problems. Services, in essence, are intangible; it is difficult to separate their production from consumption; they cannot be easily storied; and there is generally considerable variation in the quality of the service delivered from one supplier to the next (Zeithaml, Parasuraman and Berry, 1985). A major concern of this intangibility associated with educational services is the difficulty that it creates for evaluation of the service prior to its purchase. Most prospective students rely on word of mouth when making decisions on overseas study (Harris and Rhall, 1993). What has been revealed from this discussion is that at least two essential components impact institutional internationalization: the level of internationalization that the institution has chosen to engage in and the mobility of critical resources. It is on these two constructs that we have built our proposed model of institutional internationalization.

\section{A Model of Institutional Internationalization}

Our model examines a number of stages that academic institutions can choose from to accomplish their goals of internationalization. There is no pre-defined entry point suggested for institutions to begin the internationalization process, although a common reference point might be to examine inbound international resources. It is also highly likely that institutions will engage in simultaneous activities, related to the models components. We propose that each of the following four quadrants can have a bearing not only on institutional decision making but also on the academic professorate career development as well.

\section{Figure 1: Model of Academic Internationalization}

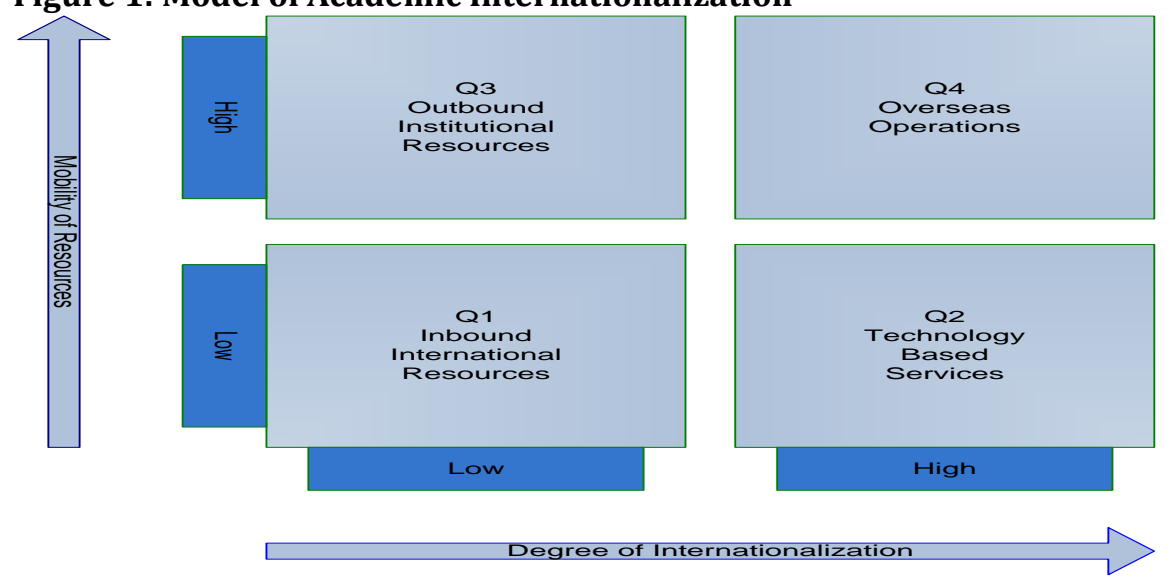

Model Stages: Inbound international resources - Inbound international resources include students coming to study from foreign locations, as well as faculty and other scholars coming to teach or conduct research at institutions abroad. The early stages of internationalization at educational institutions are typically dependent upon international students traveling abroad in search of educational opportunities. In the past, this level of internationalization required little effort on the part of institutions beyond the normal processing of qualified applicants into the institution. The institution benefits from the cultural diversity that this influx of students affords their campus, even though this diversity may be fragmented, due to the origin of the 
applicant and not sustained, due to the temporary and transient nature of students, the impact of immigration laws and the rising costs of studying abroad. Much can be gained from having a culturally diverse environment for all members of the institution. Students bring a wealth of "country-specific" knowledge that can be useful in research and classroom environments. There has been a significant trend in international education in recent years, as American colleges adopt new, more aggressive, and more strategic approaches to foreign student recruitment, often in conjunction with private-sector partners. Colleges and universities can no longer expect international students to show up at their doorsteps. Interest has been so great that the International Consultants for Education and Fairs (ICEF), an international-education recruitment company that matches colleges with recruiting agents, had to add additional North American workshops (Fischer, 2010). Survey results indicated a steady increase in university level funding for staff travel to recruit international undergraduates between 2001 and 2011 (American Council on Education, 2012). Institutions that consider this route should be aware of any bureaucratic roadblocks, such as state-spending rules at many public universities that can complicate the payment of commissions to such organizations. In addition to student recruitment, visiting international faculty can be an additional source of cultural diversity. Institutions have more control over this activity as they decide on the number of faculty accepted into their programs. Institutions have to decide whether to seek out junior faculty to possibly fill future open positions or prominent scholars to boost the image and impact of current programs. Home faculty benefit by interfacing with their international counterparts and students. Depending upon the initiative taken, this can be an opportunity for faculty to consider collaborative research agendas as well as learn about teaching techniques with in the visitor's home country. The Fulbright Scholar Program, the flagship international exchange program of the US government recently indicated a high level of representation at US institutions by scholars from the Middle East/North Africa region, Latin America and sub-Saharan Africa (O'Hara, 2009).

Technology based services - As educational institutions make decisions to expand globally, but find that they have limited mobility of resources, particularly human resources, a viable option is to expand their educational services technologically through the use of online education programs. Online degree programs, which have become more notable in US colleges and universities, provide a level of flexibility for the users to engage in programs based on convenience. While the mechanism to serve the international community is available, the authors were unable to secure data indicating how many students take advantage of this option. Institutions will need to understand whether distance education is a viable part of the educational delivery system of the country that they are targeting. For example, South Korea is looking to export online education around the world to places like Southeast Asia, Africa and even the United States. Given that South Korea is a country with plenty of traditional universities and they serve a culture that reveres face-to-face interactions, online education will not be a particularly successful strategy to pursue in country (Young, 2010). The ability to economically serve a wide expanse of consumers, through online services, can allow for a greater level of internationalization for institutions, while at the same time can prove to be a source for a quality education (Florida Division of Colleges and Universities, n.d.). Advanced technological innovations such as video and audio streaming, blogging, and video conferencing have allowed institutions to simulate the traditional classroom experience, while at the same time allowing for customization of programs for consumers based on time and space requirements. This can in fact change the way in which educators participate in the educational process. Bottery (2006) suggests that technology provides the potential for the expansion of learning opportunities, but also poses a change for educators in terms of their perceived role from disseminator of information to facilitator. Several other challenges are present as well. Educators now have to deal with the anonymity of the learner and the different learning styles and experiences that they possess as well as the fact that the educator will have to reckon with their own technical competence in terms of being efficient in the use of the delivery system. Recent findings suggest a slight increase in the percentage of institutions offering technology workshops geared toward enhancing the international dimensions across courses (American Council on Education, 2012).

Outbound institutional resources - Our discussion of outbound institutional resources is defined as students and/or faculty engaging in study or research outside of the home institution in a foreign location. Previous research shows that faculty has simultaneously increased the institutions' level of internationalization as well as their own level through mobility across borders (Eastman and Smith, 1991; Mills, 1997; Schermerhorn, 1999; Welch, 1997). The mobility of faculty across borders to work in partnership with other universities allows the home institution to create strategic partnerships thus 
enhancing the concept mentioned previously in regards to political globalization. International institutions may seek out prominent faculty as visiting scholars to provide credibility to their programs. In 2008, the Spanish government created a foundation to promote Spanish higher education abroad, raising nearly $\$ 3$ million from the ministries of education, science and innovation, and foreign affairs to tap into the global network of embassies and cultural institutions to create an international marketing campaign (Labi, 2009). However, getting faculty to accept overseas assignments might not be an easy task. Van DeBunt-Kokhuis (2000) noted, "The enthusiasm of faculty members regarding international faculty mobility seems to be limited if traveling abroad is planned purely for teaching activities rather than for research. Teaching abroad leads to little or no academic credit to the individual and the engagement of substitute faculty is difficult to arrange". The push for students to go abroad for international experience is equally enticing. International work experience has gained increasing significance and is widely recognized as a vital asset (e.g. Carpenter, Sanders, and Gregersen, 2001; Sambharya, 1996) and as a potential source of competitive advantage (Spreitzer, McCall and Mahoney, 1997) for multinational companies. While the numbers of domestic US students studying abroad are one-third $(262,416)$ of the students studying from locations outside of the US, this still represents an 8.5\% increase over the previous year (Institute of International Education (IIE, 2007).

Overseas operations - Bollag (2006) discussed in the Chronicle of Higher Education that "Higher Education" had become America's hot new export. The impetus was for both academic and business reasons. While a small number of American universities have had overseas campuses for several years, the new trend that is taking hold is the growth of overseas programs for foreign students, which has recently taken place in the past decade. Specific data on the actual number of overseas campuses does not currently exist; however, the American Council on Education has plans to survey its membership with the intent of finding out the strategic implications of such actions. What is known is that there is stiff competition from both Britain and Australia in this area. While the emphasis of these operations is certainly on teaching, an equal benefit that can be derived comes through research opportunities. The learning curve on opening overseas operations has decreased for many universities as they have learned from mistakes made by themselves and others in the past. Many exploit current capabilities and core competencies and do not venture beyond this. Like their counterparts in the corporate world, finding talented personnel to take overseas assignments is difficult and like their counterparts, many must pay a premium to do so (Bollag, 2006). Because there are additional risk factors to operating in a foreign environment, institutions must take care in constructing strategic plans to accomplish this type of initiative.

Examples from the Academy: To test the relevance of our model of institutional internationalization, we embarked on finding examples that would highlight some practices that institutions, along with the professorate have developed. Appendix A is a small sample of activities that show collaborative activities that benefit both the institution and its stakeholders as they embark on the journey of internationalizing the institution. The summary provided is a snapshot of work across the academy, and it does show evidence of activities across the spectrum of our model. Many schools in this sample have engaged in a host of creative activities to bring visiting international scholars and scholarship to their campuses (Johnston and Edelstein, 1993; Green and Olson, 2008; Mills, 2010). Additionally, there has been a flurry of activity to develop interdisciplinary collaborations, particularly with the liberal arts and business schools. In many of these situations, it has been the professorate taking the lead on program development. While there has been no mention of the role of foreign languages in the internationalization process to this point, observations for the programs identified indicate that this is a critical part of internationalizing an institution. Many of the selected programs have shown a real effort in going beyond the more common languages offered and have branched out into areas that allow them to integrate more modern language skills (Arabic, Chinese, Russian) into other parts of the curriculum. The absence of more technology based service examples in the appendix deserves more detailed discussion. While many schools have adopted online education, we found little data on the impact of these programs reaching targeted populations in international markets on the part of US colleges and universities. We did however find information on the World Bank supported Global Development Learning Network (GDLN). There are several GDLN centers in operation in major capitals in Africa, Asia and Latin America that offer regular courses on development topics to a diverse range of stakeholders, including academia (Prakash, 2006). Universities throughout Africa are using this model to deliver educational services to distant learners. One important feature of the international distance learning program is the North-South dynamics: the programs' conception in the North and delivery in the South 
(Assie-Lumumba, 2008). Farleigh-Dickenson University has created the Global Virtual Faculty, which brings scholars, professionals and experts from around the globe into courses taught by FDU faculty (see appendix A for details).

Similarly, limited data exists on the numbers and types of overseas campuses, many colleges and universities have branch centers that allow both the faculty and students to gain international experience. Appendix B provides a sample of colleges and universities with overseas branches. These ventures can be quite costly and for public institutions, legislative approval could be a roadblock to their establishment. New York University's Abu Dhabi branch (NYUAD) is an example of collaborative efforts to open a successful overseas operation. Started in the fall 2010 semester with a class of about 150 students, university administrators are working hard to ensure that the campus succeeds in a region where other foreign ventures have failed or fallen short of initial hopes (Mills, 2010). The university, along with perspective students is receiving extensive financial support from the government of Abu Dhabi. To make this opportunity attractive to faculty, the positions at NYUAD are tenure track, something that is not consistent with other overseas positions. Intensive, short-term furloughs abroad, for both faculty and students are some of the key activities that dominate outbound resource activities in a number of programs. The involvement of third parties, such as corporations, providing either extern or internship experience provides an extra boost. The opportunity to collaborate with international partners brings added exposure to the process.

\section{Conclusion}

The education industry is not only growing, it is expanding rapidly across national borders. This rapid growth is due, in part, to the rapid expansion of globalization is helping to create a more internationalized environment at colleges and universities. Institutions have had to place a greater emphasis on the movement of their resources in order to keep up with this global expansion. Students and research scholars tend to be a very mobile group, seeking out opportunities wherever they are available. While there has been increased mobility with the professorate, the motivation for overseas travel needs to be carefully examined by the institution. Flexible, shorter term assignments, which also include a research component, might be replacing long-term teaching only activities. The impact of technology in the internationalization process deserves greater attention as well. The global reach of online courses has become a major strategy of many educational institutions. Online education allows institutions to capture the market of mobile adults who do not have the luxury of a fixed class schedule while also allowing institutions to penetrate foreign markets. With the rapid changes in technology, institutions must consider the investments as well as the training needed to ensure a sustainable system of delivery. Mobility and technology may intersect when it comes to flexible foreign assignments. Faculty teaching a reduce schedule overseas may need to follow-up with online instruction to ensure proper delivery of course material. Properly trained faculty in the effective use of technology is essential.

Potential for Future Research - Each component of the model lends itself to further academic investigation. The analysis of trends and patterns of student and scholar mobility can have a dramatic impact on the strategic mission of an institution. Knowing where students are coming from and what they seek in a foreign education is essential to institutional growth. The continued push for technology based services, both at home and abroad to meet the knowledge base of the $21^{\text {st }}$ century student's who are technology savvy, will require a great investment in time and resources. Understanding the acceptance of technology in education across borders will be important for institutions to move forward with activity in this area. One of the more challenging and interesting research aspects will be looking at outbound institutional resources, which may have a greater focus on the faculty. What types of overseas assignments are available and how do you get faculty motivated to take advantage of these assignments? There are a myriad of topics that can be undertaken in this area, such as: compensation issues, impact on tenure, stage of career, etc. And finally, the growing demand for overseas operations. Institutions need to explore the feasibility of either partnership or "Greenfield" operations. Aside from the obvious issues of financial investment, issues surrounding the culture of the country, governance and internal staffing will lend themselves to exciting research topics for the future. 


\section{References}

Allen, E. \& Seaman, J. (2007). Online nation: Five years of growth in online learning. Needham, MA: The Sloan Consortium.

Allen, E. \& Seaman, J. (2008). Staying the Course: Online Education in the US, 2008. Boston, MA: Babson Survey Research Group, the College Board and the Sloan Consortium.

Altbach, P. \& Lewis, L. (1996). The academic profession in international perspective. The international academic profession: Portraits of fourteen countries. Princeton, NJ: Carnegie Foundation for the Advancement in Teaching.

American Council on Education (2012). Mapping Internationalization on U.S. Campuses: 2012 edition. Washington DC: American Council on Education.

American Council on Education. (2005). An Agenda for Excellence: Creating Flexibility in Tenure Track Faculty Careers. Washington, DC: The American Council on Education.

Assie-Lumumba, N. D. (2008). The Global Development Learning Network (GDLN and Tertiary Education in Africa: Opportunities and Predicaments of Centralized Knowledge Broadcasting Programs on the World Scale. Perspectives on Global Development and Technology, 7(34), 231-258.

Berge, Z. L. (2002). Barriers to distance education and training. Quarterly Review of Distance Education, 3(4), 409-418.

Bohm, A. \& Davies, D., Meares, D. \&Pearce, D. (2002). Global student mobility: Forecasts for the Global Demand for International Higher Education. Sydney, Australia: IDP Education.

Bollag, B. (2006). America's Hot New Export: Higher Education. The Chronicle of Higher Education, 52, 44-50.

Bottery, M. (2006). Educational leaders in a globalizing world: a new set of priorities? School Leadership and Management, 26(1), 5-22.

Carpenter, M. A., Sanders, W. G. \& Gregersen, H. (2001). Bundling human capital with organizational context: The impact of international experience on multinational firm performance and CEO pay. Academy of Management Journal, 44, 493-511.

Chen, B. (2009). Barriers to adoption of technology-mediated distance education in higher education institutions. Quarterly Review of Distance Education, 10(4), 333-338.

Chen, B., Voorhees, D. \& Rein, D. (2006). Improving professional development for teaching online. Journal of Computer Information Systems, 2(1), 303-308.

Chow, P. \& Bhandari, R. (2011). Open Doors 2011 Report on International Educational Exchange. New York: Institute of International Education

Collin, A. \& Young, R. A. (2000). The Future of Career. The Future Career. R. A. Young. Cambridge, MA: Cambridge University Press, 276-98.

Driver, M. (1994). Careers: a review of personal and organizational research. Key reviews in managerial psychology. Cooper, C \&Robertson, I. (Eds.) Oxford England: Wiley, 237-269.

Eastman, V. \& Smith, R. (1991). Linking culture and instruction. Performance and Instruction, 30(2), 21-28.

Eaton, S. C. \& Bailyn, L. (2000). Career as life path: tracing work and life strategies of biotech professionals, in Morris, T. (Ed.) Career Frontiers, New Concepts of Working Lives, Oxford: Oxford University Press, 177-201.

Fischer, K. (2010). American Colleges Look to Private Sector for Global Recruiting. Chronicle of Higher Education, 1, 25.

Florida Division of Colleges \& Universities (n.d.). Education for Less. Florida Division of Colleges and

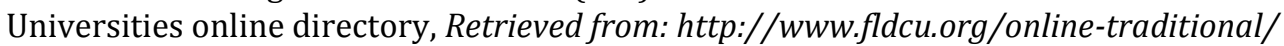

Green, M. \& Olson, C. (2008).Internationalizing the Campus: A User's Guide. Washington, DC: American Council on Education.

Green, T., Alejandro, J. \& Brown, A. H. (2009). The retention of experienced faculty in online distance education programs: Understanding factors that impact their involvement. International Review of Research in Open and Distance Learning, 10(3).

Handy, C. (1994). The Empty Raincoat. London, UK: Hutchinson.

Harris, D. R. \& Rhall, T. M. (1993). Survey of International Students, Braddon, ACT, Department of Employment and Training.

Hoovers. (2010). Industry Profile: Colleges and Universities, Hoovers, Inc. 
Hughes, R. (2008). Internationalization of Higher Education and Language Policy: Questions of Quality and Equity. Higher Education Management and Policy, 20(1), 111-128.

IIE. (2007). Atlas of Student Mobility. New York: Institute of International Education.

IIE. (2011). Measuring Impact \& Results: Our Impact by the Numbers Fulbright 2009-2010 Annual Report Retrieved on June 25, 2012 from http://www.iie.org/Who-We-Are/Annual-Report/MeasuringImpact-and-Results

Johnston Jr, J. S. \& Edelstein, R. J. (1993). Beyond Borders: Profiles in International Education. Association of American Colleges, 1818 R St., NW, Washington, DC 20009.

Kanter, R. M. (1989). Careers and the wealth of nations: a macro perspective on the structure and implications of career forms. B. S. Lawrence (Ed.) Handbook of Career Theory, Cambridge, MA: Cambridge University Press, 275-91.

Knight, J. (2002).Trade in Higher Education: The Implications of GATS, Higher Education, 39, London, UK: The Observatory on Borderless Higher Education.

Labi, A. (2009). European Universities Look Overseas for New Partnerships. The Chronicle of Higher Education, September 142009.

Mills, C. (1997). Interaction in classes at a New Zealand university: some international students' experiences. New Zealand Journal of Adult Learning, 25(1), 54-70.

Mills, A. (2010). NYU Populates a Liberal Arts Outpost in the Middle East. Chronicle of Higher Education, 11, 28-30.

OECD. (2004). Internationalization and Trade in Higher Education, Paris, France: Organization for Economic Cooperation and Development.

OECD. (2011). Education at a Glance 2011: OECD Indicators, OECD Publishing. Retrieved from http://dx.doi.org/10.1787/eag-2011-en

O'Hara, S. (2009). Internationalizing the Academy: The Impact of Scholar Mobility. Higher Education on the Move: New Developments in Global Mobility. Bhandari, R. \& Laughlin, E. (Eds.) New York: Institute of International Education, 29-48.

Porter, P. \& Vidovich, L. (2000). Globalization and higher education policy. Educational Theory, 50(4), 449468.

Prakash, S. (2006). Distance Learning: Connecting Development Practitioners, Washington, DC: World Bank.

Radford, A. (2010). Statistics in Brief Learning at a Distance Undergraduate Enrollment in Distance Education Courses and Degree. U.S. Department of Education, Washington, DC. Retrieved from http://nces.ed.gov/pubs2012/2012154.pdf

Rask, M., Strandskov, J. \& Hakonsoon, D. (2008). Theoretical Perspectives on the Internationalization of Firms. Journal of Teaching in International Business, 19(4), 320-345.

Richardson, J. \& Zikic, J. (2007). The Darker Side of an International Academic Career. Career Development International, 12(2), 164-186.

Sambharya, R. B. (1996). Foreign experience of top management teams and international diversification strategies of US multinational corporations. Strategic Management Journal, 17, 739-746.

Schermerhorn, J. R. (1999). Learning by going? The management educator as expatriate. Journal of Management Inquiry, 8(3), 246-256.

Schuster, J. H. (1994). Emigration, internationalization, and brain drain: propensities among British academics. Higher Education, 28(4), 437-452.

Simonson, M., Smaldino, S., Albright, M. \& Zvacek, S. (2006). Teaching and learning at a distance: Foundations of distance education, Upper Saddle River, NJ: Prentice-Hall.

Spreitzer, G., McCall, M. \& Mahoney, W. (1997). Early identification of international executive potential. Journal of Applied Psychology, 82, 6-29.

U.S. Department of State. (2011). 46 th Annual Report J. William Fulbright Scholarship Board, Washington, DC.

Van De Bunt-Kokhuis, S. (2000). Going Places: Social and Legal Aspects of International Faculty Mobility. Higher Education in Europe, 25(1), 47-55.

Wachter, B. (2009). Increasing Europe's Attractiveness for International Students: What Can We Learn From The Bologna Process? Higher Education on the Move: New Developments in Global Mobility. R. Bhandari and S. Laughlin. Institute of International Education, 2, 49-64.

Welch, A. (1997). The peripatetic professor: the internationalization of the academic profession. Higher Education, 34(6), 323-45. 
Young, J. R. (2010). S. Korean Colleges Aim to Export Online Education Around the World. Chronicle of Higher Education, 1(7).

Zeithaml, V. A., Parasuraman, A. \& Berry, L. (1985). Problems and Strategies in Service Marketing. Journal of Marketing, 49(3), 33-46.

Zgaga, P. (2006). Looking out: The Bologna Process in a global setting, Oslo, Norway: Ministry of Education and Research.

\section{Appendix A}

Selected Samples from Institutions

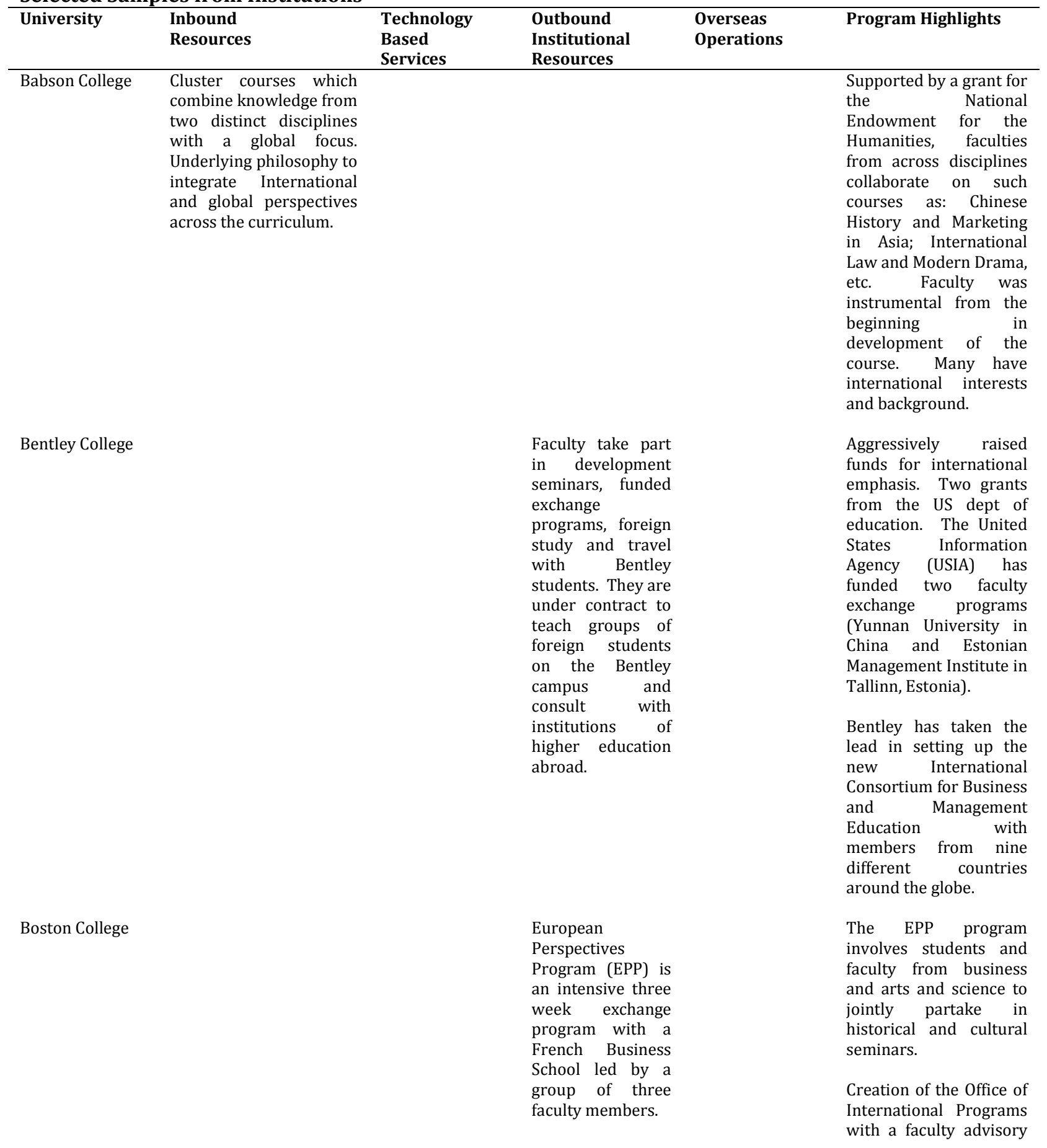


College of Staten

Island (CUNY)

Eastern

Michigan

University

Farleigh-

Dickenson

University $^{1}$

Kalamazoo

College

\section{Culture and \\ Commerce, a multifaceted four year course that combines, courses, study abroad and an internship with a NY firm with international ties.}

EMU's World College, a program in language and international trade. Program focuses on both undergraduate and graduate students.

The Global

Virtual Faculty Program brings a global dimension

to the learning experience by offering an online dialogue of different views and observations on issues being studied.GVF members come from a variety of backgrounds and include such individuals as the former head homicide

investigator for Scotland Yard, a senior journalist from India, a historian from the Caribbean, etc.

Four language houses are staffed by native speaking assistants (French, German, Japanese, and Spanish). Other on campus language programs include: Chinese, Dutch, classical Greek, Italian, and Russian.
Eighty five to ninety percent of its students study abroad

panel

The tailoring of internships is a unique and important part of the program. Built on collaboration between humanities \& social sciences, languages and international business. The program can point to several students accepting or creating international positions.

The language and international trade program has tracks in French, Spanish, German, Japanese, Chinese, and Arabic. Two-thirds of the students enrolled in the program have secured international positions. Faculty plays a key role in bringing a variety of non-traditional foreign languages to the campus.

Not the typical distance learning setup. International resources are brought to the home campuses via distance education technology

Centers

maintained by the college in Aix-en-Provence, Strasbourg, ClermontFerrand and Caen, France Munster, Hanover,
Vary broad based approach with many opportunities for faculty across disciplines to become involved in the programs. 


\begin{abstract}
New York
University² Abu

Dhabi
\end{abstract}

Ramapo College

Visiting scholars and staff and faculty exchanges are high priorities. Five percent of full time faculty member each year are visiting scholars from other countries, including the Fulbright scholars.

Robert Morris

Hosts

visiting international faculty each semester through Rooney Scholar program; About 225 graduate and undergraduates from about 40 countries attend RMU each year with the majority from Saudi Arabia

\begin{tabular}{|c|c|}
\hline St. Olaf Collage & 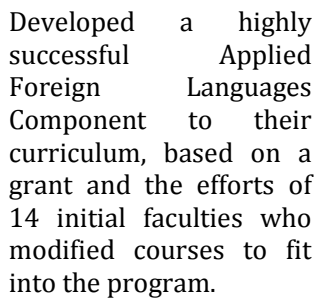 \\
\hline
\end{tabular}

Southern New International Institute Hampshire dedicated to recruiting

Erlangen and

Bonn, Germany;

Madrid and

Caceres, Spain;

the African

Nations of Kenya,

Sierra Leone and

Senegal; and

Ecuador.

Collaborative venture with the government of Abu Dhabi, UAE.
On average between 100 and 125 students participate in year; semester and two week long study abroad faculty led programs
Faculty who are hired here are tenure track, which has typically been uncommon. Students are provided with scholarships from the Abu Dhabi government to attend school here.

Several key accomplishments: $3 / 4$ of the faculty has participated in professional development seminars of an international nature; release time has been made available for travel and scholarship; a research institute, the Center for International Study has been established and new scholars are being supported by governments from around the globe.

Created Center for Global Engagement to promote and celebrate international and crosscultural educational experiences among students,

administration, and faculty in this global environment. The main focus is to internationalize the campus

Faculties integrate the language component into their regular courses, therefore building competencies across the curriculum. This program also spans more than just traditional languages and includes others such as Russian, Norwegian, and Chinese. Faculty members are incentivized for the prep work for this initiative.

Flexible two-three Partnerships in Listed by Fast Company week assignments, Malaysia and as one of the top 100 


\begin{abstract}
University international students
UCLA

The university hosts over six thousand international students, two thousand visiting scholars and a host of others with heritage that can be traced around the world. They have a faculty sponsored and supported Office of International Studies and Overseas (ISOP)Programs that supports its many and varied activities.

University of The development of California, San "Fifth College" which is Diego totally devoted to an international experience. The college draws on the expertise of about 100 faculty members across all disciplines to make it a success.

University of Hosts a Center for Michigan International Business Education and Research (CIBER).

University of Joseph H Lauder Institute Pennsylvania that provides a joint degree (MBA from Wharton and a MA from the School of Arts and Sciences)
\end{abstract}

\section{followed by online support via Blackboard}

Each year, about 200 students go abroad, along with sponsored faculty and doctoral student retreats

\section{University of California \\ Education Abroad program, which affiliates with over ninety-nine universities around the globe.}

Representative of international

corporations come to campus to hire qualified interns for the summer in the area in which their studies occur. Many have taken offers with businesses with substantial international activity.

Sends students to intern with Germany companies.

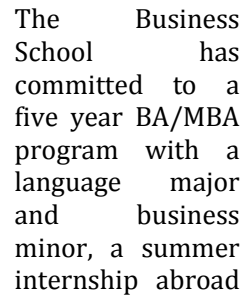

innovative companies in 2012. The only educational institution to be named on the list and ranked number 12 .

The program has been evolutionary in nature as an outgrowth from the original African Studies program, led by the current director of the ISOP.

$\begin{array}{ll}\begin{array}{l}\text { University of } \\ \text { Rhode Island }\end{array} & \begin{array}{l}\text { Creation of a unique } \\ \text { International } \\ \text { Engineering Program. } \\ \text { Focus on German, with } \\ \text { an emphasis in the } \\ \text { engineering discipline. }\end{array} \\ & \text { The university is home to } \\ \text { the German Summer } & \text { School of the Atlantic, a } \\ & \text { residential, total } \\ \text { immersion program } & \text { subsidized by the Federal } \\ & \text { Republic of Germany. }\end{array}$




$\begin{array}{llr} & & \\ \text { University of } & \begin{array}{l}\text { Created a } \\ \text { South Carolina } \\ \text { International }\end{array} & \text { Business } \\ & \text { Studies. } & \text { Multiple } \\ & \text { untraditional languages } \\ & \text { are offered. }\end{array}$

Worcester

Polytechnic Inst.

A technology focus on internationalization.

Faculty are required to supervise the student's Interactive Qualifying Project, that requires the student to define, study and recommend solutions to real world problems. and an intensive MBA experience.

Students must spend time abroad to complete the degree.
International research is a priority at the university and the International Business Center provides grants for interdisciplinary research. There are several joint ventures between liberal arts and business faculty and for several years the university hosted the prestigious, peerreviewed Journal of International Business Studies as well as its own working papers series.

Projects can be done either on or off campus, but many have international implications.

University provides financial assistance for these projects and corporate sponsorships are growing.

There is a growing network of project centers and programs staffed by WPI adjunct and full time faculty.

Source: Johnston and Edelstein (1993) Beyond Borders: Profiles of International Education; Green and Olson (2008) Internationalizing the Campus: A User's Guide1; Mills (2010) NYU Populates a Liberal Arts Outpost in the Middle East; Southern New Hampshire University and Robert Morris University (2012).

\section{Appendix B}

\begin{tabular}{ll} 
A Sampling of American Colleges Abroad \\
\hline COUNTRY and REGION & COLLEGE/UNIVERSITY \\
\hline North America & City U. (Wash); DeVry Inc.; Oklahoma City U.; U. of Phoenix \\
Canada & Alliant U.; Apollo International; City U. (Wash); Endicott College; Laureate Education \\
South America & \\
Bermuda & Webster U. \\
Brazil & Apollo International; Laureate Education \\
Chile & Laureate Education \\
Costa Rica & Laureate Education \\
Dominican Republic & Rochester Institute of Technology \\
Ecuador & Laureate Education; Troy U. \\
Honduras & Laureate Education \\
Panama & Florida State U.; Laureate Education \\
Peru & Laureate Education \\
West Indies & DeVry Inc. \\
Europe &
\end{tabular}




\begin{tabular}{|c|c|}
\hline Austria & Webster $U$. \\
\hline Belgium & Boston $U$. \\
\hline Bosnia \& Herzegovina & U. of Delaware \\
\hline Britain & U. of Chicago; Webster U. \\
\hline Croatia & Rochester Institute of Technology \\
\hline Cyprus & Laureate Education \\
\hline Czech Republic & Rochester Institute of Technology; U. of Northern Virginia \\
\hline France & Georgia Institute of Technology; Laureate Education \\
\hline Germany & Troy $U$ \\
\hline Greece & Carnegie Mellon U.; U. of Indianapolis \\
\hline Ireland & Kaplan, Inc. \\
\hline Kosovo & Rochester Institute of Technology \\
\hline Spain & Laureate Education \\
\hline Switzerland & Laureate Education; Webster $U$. \\
\hline The Netherlands & Apollo International; Webster U.; Western International U. \\
\hline \multicolumn{2}{|l|}{ Middle East } \\
\hline Abu Dhabi & New York University \\
\hline Qatar & Carnegie Mellon U.; Cornell U.; Georgetown U.; Texas A\&M U.; Virginia Commonwealth U. \\
\hline United Arab Emirates & George Mason U.; Troy U. \\
\hline \multicolumn{2}{|l|}{ Asia } \\
\hline China & $\begin{array}{l}\text { City U. (Wash); Florida International U.; Fordham U.; Lakeland College; Laureate Education; } \\
\text { Missouri State U.; Ohio U.; Oklahoma City U.; Pace U.; Stevens Institute of Technology; } \\
\text { Syracuse U.; U. of Maryland at College Park; U. of Michigan; U. of Texas at Arlington; } \\
\text { Washington U. in St. Louis; Webster U.; Western International U. }\end{array}$ \\
\hline Hong Kong & George Washington U.; Troy U. \\
\hline India & Apollo International; Champlain College; Troy U.; U. of Dayton; Western International U. \\
\hline Japan & Alliant U.; Carnegie Mellon U.; Lakeland College; Temple U. \\
\hline Malaysia & Troy $U$. \\
\hline Singapore & $\begin{array}{l}\text { George Washington U.; Georgia Institute of Technology; MIT; SUNY at Buffalo; U. of Chicago; } \\
\text { U. of Nevada at Las Vegas }\end{array}$ \\
\hline South Korea & Carnegie Mellon U. \\
\hline Sri Lanka & Troy $U$. \\
\hline Taiwan & Troy $U$. \\
\hline $\begin{array}{l}\text { Thailand } \\
\text { Oceania }\end{array}$ & Ohio State U.; Troy U.; Webster U. \\
\hline $\begin{array}{l}\text { Australia } \\
\text { US Properties }\end{array}$ & Carnegie Mellon $U$. \\
\hline Guam & Troy $U$. \\
\hline
\end{tabular}

Source: Bollag (2006) America's Hot New Export Higher Education 